Author: M Nyenti and LG Mpedi

THE IMPACT OF SADC SOCIAL PROTECTION INSTRUMENTS ON THE SETTING UP OF A MINIMUM SOCIAL PROTECTION FLOOR IN SOUTHERN AFRICAN COUNTRIES

ISSN 1727-3781

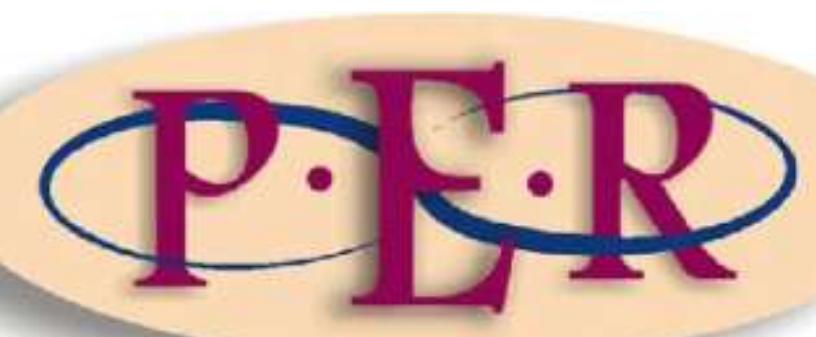

2012 VOLUME 15 No 1

http://dx.doi.org/10.4314/pelj.v15i1.8 


\section{THE IMPACT OF SADC SOCIAL PROTECTION INSTRUMENTS ON THE SETTING UP OF A MINIMUM SOCIAL PROTECTION FLOOR IN SOUTHERN AFRICAN COUNTRIES}

\section{Nyenti* and LG Mpedi**}

\section{The minimum social protection floor concept}

The concept of a social protection floor was proposed by the World Commission on the Social Dimension of Globalization in 2004, when it stated that "a certain minimum level of social protection needs to be an accepted and undisputed part of the socioeconomic floor of the global economy." 1 The concept was developed by the International Labour Organisation (the ILO) as a means to extend the scope of coverage of social protection. It denotes a set of basic social rights, services and facilities to which the global citizen should have access. It consists of a basic set of social security entitlements that are provided in addition to social insurance schemes. ${ }^{2}$

The concept is premised on the basis that it can be realised through the provision of social transfers and essential services. Access to these social transfers and essential services must be as of a right. ${ }^{3}$ Therefore, an appropriate legislative framework must be developed or any existing framework amended to uphold and protect the rights of those likely to be affected. ${ }^{4}$ The social rights, services and facilities that are provided should be at the minimum essential levels of rights as provided in human rights treaties. ${ }^{5}$ These consist of a basic set of essential transfers,

Mathias Nyenti. Doctoral Candidate (UNISA); LLM (UJ); LLB (Hons) Buea (Cameroon). Research Coordinator: Centre for International and Comparative Labour and Social Security Law (CICLASS), Faculty of Law, University of Johannesburg. Email: mnyenti@uj.ac.za.

** Letlhokwa George Mpedi. LLD (University of Johannesburg); LLM (Rand Afrikaans University); LLB (Vista University); B Juris (Vista University). Professor and Director: Centre for International and Comparative Labour and Social Security Law (CICLASS), Faculty of Law, University of Johannesburg. Email: Igmpedi@uj.ac.za.

World Commission on the Social Dimension of Globalization Fair Globalization 110.

International Organisation of Employers Concept of the Social Protection Floor 3.

Cichon, Behrendt and Wodsak UN Social Protection Floor Initiative 5.

ILO and WHO Social Protection Floor 5.

In the SADC regional context, this would entail the rights provided in the SADC Treaty (1992) and social protection instruments such as the Charter of Fundamental Social Rights in SADC 
in cash and in kind, paid to the poor and vulnerable to provide a minimum income, security and access to essential health care; and geographical and financial access to essential services such as water and sanitation, adequate nutrition, health and education. ${ }^{6}$ Therefore, the minimum social protection floor guarantees access to nationally-defined baskets of essential goods, services, and income transfers that ensure that people are not hungry, do not suffer from treatable illnesses, do not remain uneducated, do not have to resort to unsafe water, and do not remain homeless. ${ }^{7}$

The ILO remarks that the social transfers and essential services component of the minimum social protection floor must guarantee universal access to essential health services (in the sense that all residents have access to a nationally-defined set of essential health care services); income (or subsistence) security for all children through child benefits (all children have income security, at least at the level of the nationally-defined poverty line level, through transfers in cash or kind aimed at facilitating access to essential goods and services, such as nutrition, education and care); income support combined with employment guarantees through public works programmes for the working-age poor who cannot earn sufficient income on the labour market (all those in active age groups who are unable to earn sufficient income on the labour markets should enjoy a minimum income security through social assistance transfers aiming to achieve access to essential goods and services); and, income security through basic tax-financed pensions for the old, the disabled and those who have lost the main breadwinner in a family (all residents in old age and with disabilities have income security at least at the level of the nationally-defined poverty line through pensions/transfers in kind that guarantee access to essential goods and services). ${ }^{8}$ As shown in the figure below, the minimum social protection floor concept can be developed and implemented at both the

(2003), and the relevant SADC Protocols. International instruments include the International Covenant on Economic, Social and Cultural Rights (1966), the Convention on the Rights of the Child (1989) and the Convention on the Elimination of All Forms of Discrimination Against Women (1979) (see ILO and WHO Social Protection Floor 4 and 12.

ILO and WHO Social Protection Floor 5.

Cichon, Behrendt and Wodsak UN Social Protection Floor Initiative 5.

Cichon Expert Panel on Emerging Issues 5; ILO and WHO Social Protection Floor 6-7. 
international, regional and national contexts. ${ }^{9}$ However, the concept cannot be applied uniformly across the world, due to differences in national and regional experiences. It is therefore required that the concept should remain general and flexible and take into account national (or regional) context and capacity. The scope of the concept should be subject to national or regional debate and to progressive implementation. ${ }^{10}$

In the (Southern) African context, the minimum social protection floor has been defined as a basic floor of social protection beneath which no one falls, and which promotes sustainable livelihoods. ${ }^{11}$ This basic floor ensures income security for all children through family/child benefits, aimed to facilitate access to health care, education, housing and improved nutrition; access to basic social assistance for all women, since many women have family responsibilities which preclude them from undertaking formal work and have no income to support themselves or their children; access to social pensions and basic services for all older people; access to assistance that provides income support for all people with disabilities, and access to mainstream health care, education, housing and empowerment, given the reduced employment opportunities and the extra costs associated with disability; access to basic services for all migrant and marginal communities, including pastoralists; access to the life-saving treatment and basic social services that ensure improved living standards for all people living with HIV and AIDS; and access to basic services for the unemployed and any other people that fall beneath the basic floor of social protection. $^{12}$

The rights and transfers provided under the minimum social protection floor should guarantee effective access to goods and services for all throughout their life cycle. Access should therefore be provided to children, to persons in the active age groups and to older persons; while paying particular attention to vulnerable groups by considering further key characteristics that cut across all age groups (including gender, socio-economic status, ethnicity, disabilities, or belonging to a population

ILO and WHO Social Protection Floor Initiative 4.

International Organisation of Employers Concept of the Social Protection Floor 5.

Africa Civil Society Platform for Social Protection 2008 www.ipc-undp.org 1.

Africa Civil Society Platform for Social Protection 2008 www.ipc-undp.org 1. 
exposed and/or highly sensitive to adverse external effects such as natural hazards, intense climate phenomena). ${ }^{13}$ The minimum social protection floor will further ensure the protection of traditionally particularly vulnerable groups, such as migrant workers and people living with HIV/AIDS, and will lead to the greater empowerment of women in families, communities and societies. ${ }^{14}$

The Social protection floor (as shown in the 'social security staircase' below) comprises of four key guarantees, i.e.: access to essential health care, income security for children, assistance for the unemployed and poor, and income security for the elderly and persons with disabilities. However, the minimum social protection floor does not operate in isolation. It is interlinked with mandatory social insurance and voluntary insurance.

\section{SOCIAL SECURITY STAIRCASE}

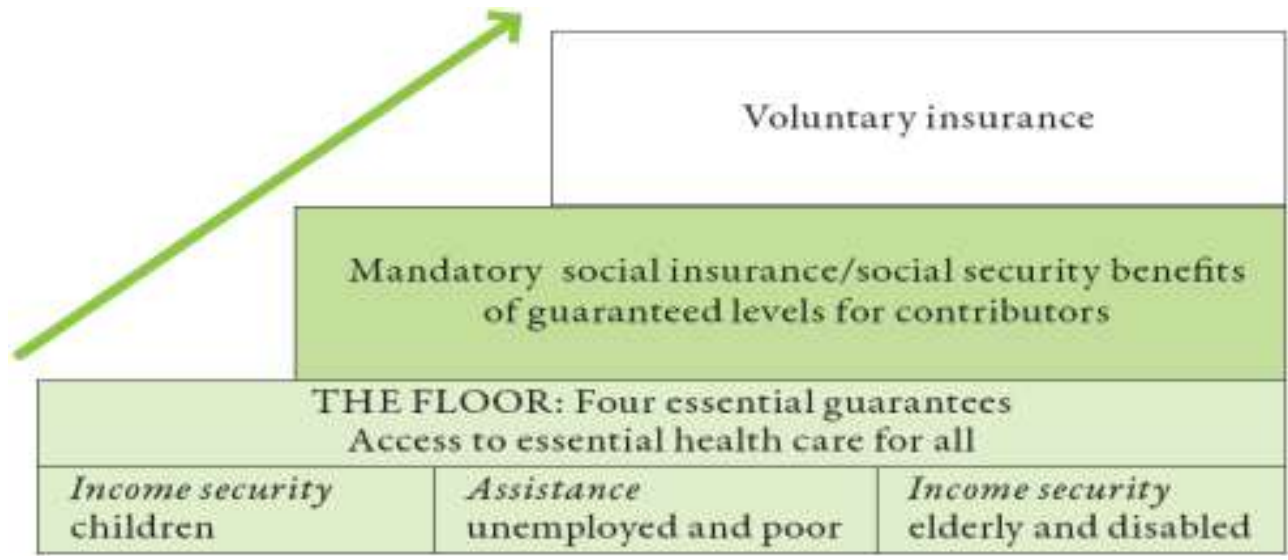

Source: ILO Extending Social Security 20.

\section{The Social Protection Floor Initiative}

A Global Initiative for a Universal Social Protection Floor (hereinafter called Social Protection Floor Initiative or SPF-I) was adopted by the United Nations System Chief Executives Board in April 2009 as one of nine initiatives to respond to the crisis in social protection coverage. ${ }^{15}$ The Social Protection Floor Initiative is thus a

ILO and WHO Social Protection Floor 5.

ILO and WHO Social Protection Floor 7.

The crisis in social protection coverage refers to the limited scope of coverage in terms of social protection coverage worldwide. According to the ILO, four out of five people worldwide do not 
recognition that the provision of a basic level of social protection and a decent life for everyone (universal social protection) is a necessity as well as an obligation in terms of international human rights instruments. ${ }^{16}$

The Social Protection Floor Initiative is not an international human rights instrument. It also does not create additional parallel processes (and obligations) at the country (or regional) level but rather establishes Social Protection Floor policies as an integral part of existing national, regional and United Nations (UN) planning processes. ${ }^{17}$ It aims to provide a benchmark for the achievement of the basic social protection guarantees in international human rights instruments. The initiative further promotes and assists in the implementation of the social protection guarantees at the international (e.g. UN), regional (e.g. Africa, European Union (EU)) and country levels. This is achieved through joint UN agency responses where cutting-edge advice in their respective areas of expertise provided by each UN agency ensures the optimal use of experts, resources and logistical support. ${ }^{18}$

benefit from a level of social protection that allows them to realise their human rights (see ILO and WHO Social Protection Floor Initiative 2). The need for the extension of basic universal social protection is even more acute in Africa. The ILO estimates that only an estimated 5-10 percent of the working population has some social security coverage in sub-Saharan Africa; while social security coverage generally ranges from 20-60 percent of the population in middleincome African countries (see ILO [date unknown] www.ilo.org).

16 ILO and WHO Social Protection Floor Initiative 2. The need for basic universal social protection is even more acute in Africa. According to the ILO, only an estimated 5-10 percent of the working population has some social security coverage in sub-Saharan Africa; while social security coverage generally ranges from 20-60 percent of the population in middle-income African countries (see ILO [date unknown] www.ilo.org).

17 As an example, the Social Protection Floor Initiative supports regional commitments to social security, such as the 2009 African Union (AU) Social Policy Framework for Africa and the country level social protection programmes in South Asia - see ILO and WHO Social Protection Floor Initiative 4. 


\section{ROLE PLAYERS IN THE SOCIAL PROTECTION FLOOR AGENDA}

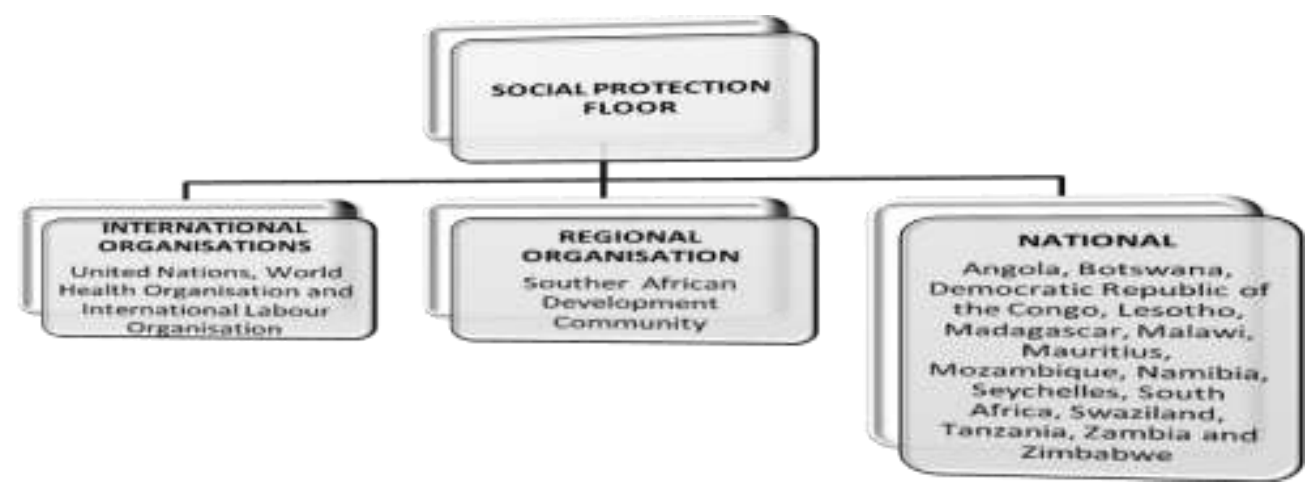

\section{SADC social protection instruments: towards a minimum floor}

The Southern African Development Community (SADC) has as its mission the promotion of sustainable and equitable economic growth and socio-economic development through efficient production systems, deeper cooperation and integration, good governance, and durable peace and security, so that the region emerges as a competitive and effective player in international relations and the world economy. ${ }^{19}$

In order to achieve its mission, member states have concluded various instruments, such as Charters, Protocols, and Codes. Amongst these are instruments which are geared towards the promotion of adequate social protection in the region. SADC social protection-related instruments include the Declaration and Treaty of the SADC (the SADC Treaty), the Charter of Fundamental Social Rights in the SADC (the Social Charter), the Code on Social Security, the Protocol on Gender and Development, the Protocol on Health, the Protocol on Education and the Draft Protocol on Facilitation of Movement of Persons in the SADC. The SADC Treaty and Protocols to the Treaty, ${ }^{20}$ and the Social Charter are legally-binding instruments that must be implemented by SADC Member States. However, the Code on Social

See the SADC [date unknown] www.sadc.int.

In terms of Article 1 of the SADC Treaty, a Protocol is an instrument of implementation of the Treaty, having the same legal force as the Treaty. 
Security is non-binding, and merely provides guidelines on the implementation of social security. ${ }^{21}$

The social protection instruments therefore aim at setting baseline standards (a minimum floor) at the regional and country level with regard to the most basic social protection functions that a Member State has to fulfil. In evaluating the establishment of a minimum social protection floor by the SADC social protection, it must be ascertained if these instruments are appropriate as the legislative framework developed to uphold and protect the rights of those (likely to be) affected. The evaluation will assess if the instruments meet the requirements of the minimum social protection floor, including the provision of access to a set of basic social rights, services and facilities for every SADC citizen; ensuring that access to these social transfers and essential services is a right; guaranteeing the social rights, services and facilities at the minimum essential levels of rights as provided in human rights treaties; providing a basic floor of social protection below which no one falls, and which promotes sustainable livelihoods; and providing to the poor and vulnerable a minimum income, security, access to essential health care; and geographical and financial access to essential services such as water and sanitation, adequate nutrition, health and education. The provisions in the SADC social security instrument guaranteeing a minimum floor are summarised in tables below.

\subsection{Declaration and Treaty of SADC}

The Declaration and Treaty of the SADC (hereafter called SADC Treaty) contains provisions that have an impact on the social protection position of the people of the region. The Treaty is legally binding, and provides the framework for SADC member states to co-ordinate, harmonise and rationalise their policies and strategies for sustainable development in all areas of human endeavour. The Treaty foresees the

21 The Code aims to provide Member States with strategic direction and guidelines in the development and improvement of social security schemes, in order to enhance the welfare of the people of the SADC region; to provide SADC and Member States with a set of general principles and minimum standards of social protection, as well as a framework for monitoring at national and regional levels; and to provide SADC and Member States with an effective instrument for the coordination, convergence and harmonisation of social security systems in the region - Article 3 of the Code on Social Security in SADC. 
development of minimum standards and the establishment of harmonised programmes of social security throughout SADC. The existence of minimum standards for social protection implies that a basic minimum level of social protection will be provided to every SADC citizen, irrespective of where in the region he or she resides. This therefore foresees the coordination, harmonisation and rationalisation of social protection policies throughout the SADC region. The Treaty commits member states to various fundamental principles, including human rights. ${ }^{22}$ The Treaty further commits member states to fundamental principles that are relevant to the development of social protection, including solidarity, human rights, equity, balance and mutual benefit.

The objectives listed in Article 5 of the Treaty include the promotion of social development in the region. Specific social protection-related objectives include poverty alleviation with the ultimate objective of its eradication, enhancement of the standard and quality of life of the people of Southern Africa, and support for the socially disadvantaged through regional integration. Member states undertake to combat HIV/AIDS or other deadly and communicable diseases; to ensure that poverty eradication is addressed in all SADC activities and programmes; and to mainstream gender in the process of community building. ${ }^{23}$

To achieve its objectives the SADC has undertaken (inter alia) to harmonise the political and socio-economic policies and plans of Member States; to encourage the people of the region and their institutions to take initiatives to develop economic, social and cultural ties across the region and to participate fully in the implementation of the programmes and projects of the SADC; to create appropriate institutions and mechanisms for the mobilisation of the requisite resources for the implementation of the programmes and operations of the SADC and its institutions; and to develop such other activities as Member States may decide in furtherance of the objectives of the Treaty. ${ }^{24}$ 
SADC member states also undertake to adopt adequate measures to promote the achievement of the objectives of the SADC, and to refrain from taking any measure likely to jeopardise the sustenance of its principles, the achievement of its objectives and the implementation of the provisions of the Treaty; and not to discriminate against any person on the grounds of gender, religion, political views, race, ethnic origin, culture, ill health, disability, or such other ground as may be determined by the Summit. Member states also agree to conclude such protocols as may be necessary in each area of co-operation, which shall spell out the objectives and scope of and institutional mechanisms for co-operation and integration. ${ }^{25}$

These objectives therefore envisage a regional collaborative approach, as they can be achieved only through the development of regional social security mechanisms. The SADC's vision and common agenda are also geared towards the attainment of social protection objectives. Social protection (-related) areas/interventions are specifically raised in Article 21 as areas of cooperation between states. These include food security, human development and social welfare.

However, the SADC Treaty does not display strong incentives for the development of (minimum) social protection measures. The principle of non-discrimination contained in Article 6(2) is a closed list, and does not include the prohibition of discrimination based on nationality/citizenship.

\subsection{The Charter of Fundamental Social Rights in the SADC}

The Charter of Fundamental Social Rights makes comprehensive provision for the establishment of harmonised social protection programmes throughout the Region. Article 3.2 requires of member states to observe the basic rights referred to in the Charter. In addition, Article 3 guarantees the protection and enforcement in the SADC region of all of the rights protected in international instruments. Therefore, although this is not specifically stated, the Social Charter extends the minimum social protection floor envisaged in international human rights treaties to the SADC region. As a result, it requires that the social rights, services and facilities that are

Article 22 of the SADC Treaty. 
provided in the SADC region should be at the minimum essential levels of the international rights instruments.

The Charter recalls the objectives of the SADC Treaty. ${ }^{26}$ Equality of treatment and of opportunities between men and women in the area of social protection is required, as well as the development of reasonable measures to enable men and women to reconcile their occupational and family obligations. ${ }^{27}$ The protection of children and young people is emphasised, ${ }^{28}$ while member states undertake to create an enabling environment to protect the elderly (in accordance with arrangements applying to each country). The protection of the elderly relates both to workers who made provision for retirement insurance and to every other person who has reached retirement age but did not make provision for retirement and who does not have other means of subsistence. The Charter stipulates that on retirement every worker in the region should be able to enjoy resources affording him/her a decent standard of living, including equity in post-employment security schemes. ${ }^{29}$ In addition, persons who retire without making any provision for retirement insurance coverage must be entitled to adequate social assistance, including medical care, so as to be able to provide for their basic needs. ${ }^{30}$ Member states are required to ensure that persons with disabilities, irrespective of the origin and nature of their disability, are entitled to comprehensive additional concrete measures aimed at improving their social and professional integration. ${ }^{31}$

The Charter seeks to ensure the social protection both of workers and of the unemployed. In terms of Article 10, SADC member states are required to create an enabling environment such that every worker in the SADC Region shall have a right to adequate social protection and shall, regardless of status and the type of employment, enjoy adequate social security benefits. Persons who have been

26 The Charter refers to the $S A D C$ Treaty and recalls the objectives contained in a 5 of the SADC Treaty such as to achieve development and economic growth, alleviate poverty, enhance the standard and quality of life of the peoples of Southern Africa, and support the socially disadvantaged through SADC regional integration.

Article 6(c) of the Social Charter.

Article 7 of the Social Charter.

Article 8(a) of the Social Charter.

Article $8(b)$ of the Social Charter.

Article 9 of the Social Charter. 
unable to either enter or re-enter the labour market and have no means of subsistence shall be able to receive sufficient resources and social assistance.

The requirement that persons who have been unable to either enter or re-enter the labour market and have no means of subsistence should be able to receive sufficient resources and social assistance could be interpreted as encompassing the "rights of access to food, water, housing, health care and social security." ${ }^{32}$ Such an interpretation would imply that every SADC member state is required "to ensure the provision of the bare essentials each poor citizen needs to live a minimally decent life." ${ }^{33}$ This is, in accordance with the minimum social protection floor concept, a set of basic social rights, services and facilities to which the global (SADC) citizen should have access.

Member states must also establish baseline standards and harmonise other socialprotection-related areas such as paid maternity leave and occupational health and safety protection. ${ }^{34}$ The Charter mandates regional structures and country institutions to ensure its implementation. ${ }^{35}$ Article 16(2) requires that these institutions and structures promote social legislation and equitable growth within the Region and prevent the non-implementation of the Charter.

The Social Charter promotes the establishment of a minimum social protection floor as it underpins the need for the provision of social protection for the unemployed and vulnerable (as well as for workers). It also requires the protection of young people, the elderly (both of retired workers with a pension and of the destitute) and the disabled. The requirement of equal treatment indicates that men and women will have equal access to social security. This implies that the establishment of comprehensive systems of social security in the SADC member states is envisaged.

The Charter also requires the adoption of minimum social protection standards throughout the SADC region. The Charter, therefore, makes provision for the

Moyo 2010 ESR Review 12.

Moyo 2010 ESR Review 12.

Article 11(a) of the Social Charter.

Article 16(1) of the Social Charter. 
establishment of harmonised minimum country-specific social protection programmes in the SADC region. It also adopts a flexible approach, similar to the approach proposed in the minimum social protection floor concept (and in other international and/or multilateral instruments). Such a flexible approach is consistent with the SADC principle of variable geometry, i.e. the principle according to which a group of member states could move faster on certain activities and the experiences learnt are replicated in other member states. This is done by stipulating the principles that should apply at the regional and country levels, such as in Article 2(1)(e), ${ }^{36}$ Article 3(1), ${ }^{37}$ Article 5, ${ }^{38}$ Article 11(a), ${ }^{39}$ and Article $12 .{ }^{40}$

\subsection{The Code on Social Security in the SADC}

The Code on Social Security in the SADC is not a binding document. It merely provides member states with strategic direction and guidelines in the development and improvement of social security schemes, in order to enhance the welfare of the people of the SADC region. ${ }^{41}$ It provides Member States with a set of general principles and minimum standards of social protection, as well as a framework for monitoring at national and regional levels. ${ }^{42}$ It further provides Member States with an effective instrument for the coordination, convergence and harmonisation of social security systems in the region. ${ }^{43}$

36 Article 2(1)(e) states that the objective of the Charter is to facilitate, through close and active consultations among social partners and in a spirit conducive to harmonious labour relations, the promotion of the establishment and harmonisation of social security schemes.

37 In terms of a 3(1), the Charter embodies the recognition by governments, employers and workers in the Region of the universality and indivisibility of basic human rights proclaimed in instruments such as the United Nations Universal Declaration of Human Rights, the African Charter on Human and Peoples' Rights, the Constitution of the ILO, the Philadelphia Declaration and other relevant international instruments. Member States undertake to observe the basic rights referred to in the Charter.

Article 5 requires Member States to establish a priority list of ILO Conventions; and to take appropriate action to ratify and implement relevant ILO instruments and as a priority the core ILO Conventions.

Article 11(a) requires the creation of an enabling environment so that harmonisation of minimum requirements laid down in labour legislation and in particular the introduction of equitable basic working and living conditions, the specifications of minimum rest periods, annual paid leave, compassionate leave, paid maternity leave, occupational health and safety protection, and the stipulation of acceptable rules and compensation for overtime and shift work are achieved. Member States are required to seek to protect health, safety and the environment.

Article $3(1)$ of the Code.

Article 3(2) of the Code.

Article 3(3) of the Code. 
The Code requires each SADC Member State to maintain its social security system at a satisfactory level at least equal to that required for ratification of the ILO Social Security (Minimum Standards) Convention 102 of $1952 .{ }^{44}$ However, the Code employs concepts and principles (such as the need for a multi-actor approach to the realisation of social protection and the principle of variable geometry $)^{45}$ which ensure flexibility in the achievement of universal social protection by SADC countries. ${ }^{46}$

The Code guarantees a right to social security, ${ }^{47}$ both social insurance ${ }^{48}$ and social assistance. ${ }^{49}$ It also guarantees other social protection-related contingencies, such as healthcare ${ }^{50}$ maternity and paternity $;{ }^{51}$ death and survivor benefits; ${ }^{52}$ retirement and old age, ${ }^{53}$ unemployment and underemployment; ${ }^{54}$ occupational injuries and diseases ${ }^{55}$ as well as political conflict and natural disasters. ${ }^{56}$ The Code also protects other aspects of the set of basic social rights, services and facilities that make up the minimum social protection floor, such as the rights to health, education, transport, housing, water and electricity. ${ }^{57}$

The Code ensures social protection for some particularly vulnerable categories of persons, such as women, ${ }^{58}$ people with disabilities, ${ }^{59}$ families,${ }^{60}$ children and young people, ${ }^{61}$ and migrants, foreign workers and refugees. ${ }^{62}$ Article 17 of the Code deals with migrants, foreign workers and refugees, and therefore encourages member

Article 4.3 of the Code.

The multi-actor approach to the realisation of social protection recognises that it is not only the state that is responsible for the provision of social protection; while the principle of variable geometry is the principle where a Member State or a group of Member States can move faster on certain activities and the experiences learnt are replicated in other Member States.

Article 2(2) of the Code.

Article 4 of the Code.

Articles 5 of the Code.

Article 6 of the Code.

Articles 7 of the Code.

Article 8 of the Code.

Article 9 of the Code.

Article 10 of the Code.

Article 11 of the Code.

Article 12 of the Code.

Article 18 of the Code.

Article 20 of the Code.

Article 13 of the Code.

Article 14 of the Code.

Article 15 of the Code.

Article 16 of the Code.

Article 17 of the Code.
} 
states to ensure that all lawfully employed migrants are protected through the promotion of certain core principles. ${ }^{63}$ In terms of two of these principles migrant workers should, firstly, be able to participate in the social security schemes of the host country ${ }^{64}$ and, secondly, enjoy equal treatment alongside citizens within the social security system of the host country. ${ }^{65}$ Member states are further encouraged to introduce, by way of national legislation and bi- or multilateral arrangements, cross-border co-ordination principles - such as the maintenance of acquired rights, the aggregation of insurance periods, and the exportability of benefits. ${ }^{66}$ The Code also requires that illegal and undocumented migrants are provided with basic minimum protection and should enjoy coverage according to the laws of the host country. ${ }^{67}$ Social protection should also be provided to refugees in terms of international human rights instruments. ${ }^{68}$

\subsection{SADC Protocol on Health}

Article 22(1) of the SADC Treaty requires member states to conclude a series of protocols to give effect to the aims and objectives of the Treaty. As a result, several Protocols have been adopted. Human resource development and social welfare are some of the areas identified in article 21(4) of the Treaty that have direct implications for social protection within Southern Africa. Although Protocols have been concluded on various issues relating to trade, economic integration and cooperation, no specific Protocol on social protection issues has been adopted. The Protocol on Health seeks to realise the minimum social protection floor guarantee of access to essential health care for all.

Article 2 of the protocols stipulates the guiding principles for the implementation of the objectives of the Protocol. The Protocol is to be implemented through striving for

Article 17 of the Code.

Article 17(2)(a) of the Code.

Article 17(2)(b) of the Code.

Article 17(2)(d) and (e) of the Code. This is also made clear as far as pension arrangements in the region are concerned. According to a 10.5: "Member States should aim at achieving equality of access, as well as the maintenance and aggregation of social security contributions and benefits and the aggregation of insurance periods on a cross-country basis among Member States, through national laws and bilateral and other arrangements."

67 Article 17.3 of the Code.

68 Article 17.4 of the Code. 
the formulation of regional health policies and strategies consistent with the principles in Article 4 of the SADC Treaty; through promoting, co-ordinating and supporting the individual and collective efforts of State Parties to attain an acceptable standard of health for all their people; through a commitment to the primary health care approach; through promoting health care for all through providing better access to health services; and through ensuring equitable and broad participation for mutual benefit in regional co-operation in health.

The Protocol seeks to promote effective regional collaboration and mutual support to identify, promote, co-ordinate and support those activities that have the potential to improve the health of the people of the Region; to co-ordinate regional efforts on epidemic preparedness, mapping, prevention, control and where possible the eradication of communicable and non-communicable diseases; to promote and coordinate the development, education, training and effective utilisation of health personnel and facilities; to facilitate the establishment of a mechanism for the referral of patients for tertiary care; to foster co-operation and co-ordination in the area of health with international organisations and co-operating partners; to promote and coordinate laboratory services in the area of health; to develop common strategies to address the health needs of women, children and other vulnerable groups; and to progressively achieve equivalence, harmonisation and standardisation in the provision of health services in the Region.

The Protocol on Health provides for a system of co-operation to address health issues and establish institutional mechanisms to implement the Protocol. The Protocol directly addresses the issue of health as a prerequisite for sustainable human development and increased productivity in SADC member states. The Preamble recognises that close co-operation in the area of health is essential for the effective control of communicable diseases, non-communicable diseases and for addressing common health concerns in the region, and aspires to offer a full range of cost effective and quality integrated health services through regional co-operation.

Relatively little is foreseen in the Protocols that might have an impact on social protection, as the regulation is in vague and broad terms. This suggests that the 
issue of (a minimum floor of) social protection is not accorded the priority required in terms of the aims and provisions of the Treaty and Declaration of the SADC. ${ }^{69}$

SOCIAL PROTECTION GUARANTEES IN SADC INSTRUMENTS

\begin{tabular}{|c|c|c|}
\hline \multirow[t]{4}{*}{$\begin{array}{l}\text { FOUR } \\
\text { ESSENTIAL } \\
\text { GUARANTEES }\end{array}$} & $\begin{array}{l}\text { SOCIAL } \\
\text { PROTECTION } \\
\text { INSTRUMENTS }\end{array}$ & RELEVANT ARTICLES \\
\hline & Social Charter & $\begin{array}{l}\text { Article } 12 \text { (Protection of health, safety and the } \\
\text { environment) }\end{array}$ \\
\hline & $\begin{array}{l}\text { Code on Social } \\
\text { Security }\end{array}$ & Article 7 (Provision of health care services) \\
\hline & $\begin{array}{l}\text { Protocol on } \\
\text { Health }\end{array}$ & All (Collaboration on health) \\
\hline \multirow[t]{2}{*}{$\begin{array}{l}\text { Income security: } \\
\text { Children }\end{array}$} & Social Charter & $\begin{array}{l}\text { Article } 7 \text { (Protection of children and young } \\
\text { people) }\end{array}$ \\
\hline & $\begin{array}{l}\text { Code on Social } \\
\text { Security }\end{array}$ & $\begin{array}{l}\text { Article } 16 \text { (Protection of children and young } \\
\text { people) }\end{array}$ \\
\hline \multirow{2}{*}{$\begin{array}{l}\text { Assistance: } \\
\text { Unemployed and } \\
\text { poor }\end{array}$} & Social Charter & Article 10(2) \\
\hline & $\begin{array}{l}\text { Code on Social } \\
\text { Security }\end{array}$ & $\begin{array}{lccc}\text { Article } 11 & \text { (Protection against } & \text { un-/under- } \\
\text { employment) } & & & \end{array}$ \\
\hline \multirow{2}{*}{$\begin{array}{lr}\text { Income } & \text { security: } \\
\text { Elderly } \quad \text { and } \\
\text { persons with } \\
\text { disabilities } & \end{array}$} & Social Charter & $\begin{array}{l}\text { Article } 8 \text { and Article } 9 \text { (Social and labour law } \\
\text { protection of elderly persons; and Social and } \\
\text { labour law protection of persons with disabilities) }\end{array}$ \\
\hline & $\begin{array}{l}\text { Code on Social } \\
\text { Security }\end{array}$ & $\begin{array}{l}\text { Article } 10 \text { and Article } 14 \text { (Protection of the } \\
\text { elderly and persons with disabilities) }\end{array}$ \\
\hline
\end{tabular}

Apart from the provisions that support the notion of a minimum social protection floor, these instruments provide for mandatory social insurance and voluntary insurance.

69 Committee of Inquiry Social Security 561. 


\begin{tabular}{|c|c|c|}
\hline $\begin{array}{l}\text { CONTRIBUTORY } \\
\text { SCHEMES }\end{array}$ & $\begin{array}{l}\text { SOCIAL PROTECTION } \\
\text { INSTRUMENTS }\end{array}$ & RELEVANT ARTICLES \\
\hline \multirow[t]{2}{*}{ Voluntary insurance } & Social Charter & $\begin{array}{l}\text { Article } 10(1) \text { (Establishment of } \\
\text { social insurance schemes) }\end{array}$ \\
\hline & Code on Social Security & $\begin{array}{l}\text { Article } 6 \text { (Establishment of social } \\
\text { insurance schemes and } \\
\text { provision of benefits) }\end{array}$ \\
\hline \multirow[t]{2}{*}{$\begin{array}{l}\text { Mandatory } \\
\text { insurance }\end{array}$} & Social Charter & $\begin{array}{l}\text { Article 10(1)(Establishment of } \\
\text { social insurance schemes) }\end{array}$ \\
\hline & Code on Social Security & $\begin{array}{l}\text { Article } 6 \text { (Establishment of social } \\
\text { insurance schemes and } \\
\text { provision of benefits) }\end{array}$ \\
\hline
\end{tabular}

\subsection{The role and impact of the SADC in the implementation of a minimum floor}

The implementation of the provisions of the Treaty and various regional instruments geared towards the promotion of social protection in the region is facilitated by the SADC through its various institutions. The SADC comprises inter alia of the Integrated Committee of Ministers (ICM) ${ }^{70}$ the Secretariat; ${ }^{71}$ the Tribunal ${ }^{72}$ and the National Committees. ${ }^{73}$ The SADC has also established directorates, one of which is

70 The Integrated Committee of Ministers comprises of at least two ministers from each Member State, and is meant to ensure the policy guidance, co-ordination and harmonisation of crosssectoral activities.

71 It is the principal executive institution of SADC responsible for the strategic planning and management of SADC programmes, the implementation of decisions of SADC policy organs and institutions such as the Summit, the Council and the Troikas, and the coordination and harmonisation of the policies and strategies of Member States, for instance.

72 The Tribunal was entrusted with the responsibility of ensuring adherence to, and proper interpretation of the provisions of the SADC Treaty and subsidiary instruments, and to adjudicate upon disputes referred to it. However, it must be noted that the SADC Tribunal was dissolved on 20 May 2011 and expressly barred from hearing any new or pending cases. A new Tribunal is envisaged, with a different jurisdiction and a new membership, once SADC Ministers of Justice/Attorneys General have amended the relevant SADC legal instruments e.g. the SADC Treaty and the Protocol on the Tribunal (the Protocol) and submitted a progress report to the Summit in August 2011 and a final report to the Summit in August 2012.

73 These are national-level SADC institutions in each SADC Member State, to be comprised of key stakeholders notably government, the private sector and civil society in each Member State. The 
the directorate of social and human development and special programmes. Within the directorate of social and human development and special programmes is the Employment and Labour Sector (ELS). Some of the functions of the SADC/ELS are to promote the establishment and harmonisation of social security schemes; to promote equity and the protection of vulnerable groups; and to promote the development of institutional capacities as well as vocational and technical skills in the region. ${ }^{74}$ The ELS encourages accession to the SADC social protection instruments, and also provides a platform for resolving issues of implementation. It also suggests common programmes, definitions, application procedures and waiting periods, thereby encouraging conformity among country systems. ${ }^{75}$ In addition, there is also the SADC Non-Governmental Organisations (NGO) Forum which provides a sub-regional civil society voice in SADC affairs. ${ }^{76}$

\subsection{Preliminary observations}

Assessed against the aforementioned 'social security staircase', it could be argued that the SADC social protection instruments set an ideal framework within which member states (at a regional and national level) can provide a minimum social protection floor to vulnerable members of their populace. This is apparent from the review of the SADC social protection instruments and the summary in the table (Social protection guarantees in SADC instruments) above.

When dealing with the social protection instrument in the SADC and the 'social protection' staircase, it should be noted that the SADC is an organisation of a wholly inter-governmental character. This is evident mainly from the fact that the SADC is based on the principle of the sovereign equality of all member states. Despite that, its member states - which are also members of a variety of international organisations including the UN, the ILO and the World Health Organisation (WHO) -

main functions of a National Committee are to provide inputs at the national level on the formulation of regional policies and strategies and the SADC Programme of Action, as well as to coordinate and oversee the implementation of the these programmes at the national level. The Committees are also responsible for the initiation of SADC projects and issue papers as an input into the preparation of the regional strategies.

Fultz and Pieris Social Protection for Migrant Workers 16.

SADC 2006 www.ansa-africa.net 4. 
should by virtue of such membership consider the hard and soft law of such organisations dealing with social protection. They should strive to ensure that their reformed social protection systems comply with their regional and international law obligations as well as the (social protection and related) ethos and aspirations of the SADC and the international organisations to which it belongs. Most of the SADC social protection instruments are soft law. However, their importance and relevance should not be underestimated. For instance, the Code covers a variety of contingencies which could be found in the ILO Social Security (Minimum) Convention 102 of 1952, and they are health, ${ }^{77}$ maternity and paternity, ${ }^{78}$ death and surviving, ${ }^{79}$ retirement and old age,$^{80}$ unemployment and under-employment ${ }^{81}$ and occupational injuries and diseases. ${ }^{82}$ It is notable that the Code has endeavoured to cover the aforementioned risks in a manner which is sensitive to the social, economic and political realities in the SADC region. For example, the Code requires member states, when dealing with the issue of health, to address HIV/Aids. ${ }^{83}$

Furthermore, it obliges member countries to adopt proactive policies and measures towards inclusive economic and social development so as to eradicate poverty ${ }^{84}$ and integrate the formal and non-formal aspects of the economy. ${ }^{85}$ In addition, the Code makes specific mention of specific risks that are common in the region such as political unrest and natural disasters. Article 18(1) avers that member states must make sure that that their social security systems provide protection against special and collective risks, including political conflict ${ }^{86}$ and natural disasters. ${ }^{87}$ Apart from the duty to establish and maintain social security systems, the Code imposes an
Article 7 of the Code.
Article 8 of the Code.
Article 9 of the Code.
Article 10 of the Code.
Article 11 of the Code.
Article 12 of the Code.
Article 7(8) of the Code.
Article 11(2) of the Code.
Article 11(3) of the Code.
The SADC is a relatively tranquil region. However, skirmishes still experienced in member states such as the Democratic Republic of the Congo, and the situation in Zimbabwe (which arose from the controversial fast-track land redistribution programme which was implemented in 2000) is still unstable. See Olivier and Kalula "Regional Social Security" 655; Taylor 2001 Cooperation South 49; Fultz and Pieris Social Security Schemes; and Von Benda-Beckmann and Kirsch [date unknown] www.gtz.de.
The SADC is susceptible to natural disasters such as floods and drought. 
obligation on member states to progressively raise the social security systems to a higher level, which could include achieving the meaningful coverage of everyone under the system. ${ }^{88}$ Nonetheless, this duty is subject to the realities and level of development in the member state. ${ }^{89}$ This provision is in line with the principle of variable geometry embraced by the Code, where a group of member states could move faster on certain activities and the experiences learnt replicated in other members states. ${ }^{90}$

The role and impact of the SADC in the implementation of the provisions of the Treaty and various regional instruments geared towards the promotion of social protection in the region must also be taken into account in evaluating the effectiveness of the social protection-related instruments in establishing a minimum floor in the region. The SADC promotes the establishment and harmonisation of social security schemes; equity and the protection of vulnerable groups; and the development of institutional capacities as well as vocational and technical skills in the region. It encourages the granting of access to the SADC social protection instruments, and also provides a platform for resolving issues of implementation.

\section{Social protection initiatives in SADC countries: coverage, successes and challenges}

\subsection{Social protection floor}

\subsubsection{Access to essential health care}

Health care in SADC countries is largely provided through a two-tiered system comprising of private and public sectors. Private health care is generally good. However, it is accessible mainly to a restricted number of members of the population. This is largely due to the high costs generally associated with the services rendered in that sector. Persons who hope to access the private health care services generally purchase a private health insurance policy or contribute towards a 
medical aid scheme. Medical aid contributions by persons employed in the formal sector are in most case subsidised by employers. The unemployed and informally employed are generally unable to afford private health care.

Public health care in the SADC is generally financed through general taxes and, to a lesser extent, user fees. This tier of health care is largely relied upon by those members of society who are unable to afford the private health care system. In addition, the public health systems of most SADC countries are often challenged by inadequate infrastructure and a shortage of skilled personnel. ${ }^{91}$ Furthermore, public health services are in a majority of instances inaccessible to the rural poor as they are largely located in urban or remote areas. ${ }^{92}$ Despite that, it must be said that the public health systems play a crucial role in the testing and treatment of HIV/Aids, particularly when it comes to the dispensing of free antiretroviral (ARV) therapy to medically eligible individuals. Access to the life-saving ARVs, which should be treated as essential health care in the light of the HIV/AIDS scourge in most SADC countries, is improving. For instance "[i]n Botswana, Namibia, South Africa and Swaziland, coverage of antiretrovirals for preventing mother-to-child transmission of HIV reached more than 80\%." ${ }^{93}$ Furthermore, "[b]etween 2004 and 2009, AIDSrelated deaths among children in southern Africa declined by 26\%, from 120000 [88 000-150 000] to 90000 [61 000-110 000]." M44 Moreover, "[i]n Botswana, where treatment coverage exceeds $90 \%$, the estimated annual number of Aids-related deaths fell from 18000 [15 000-22 000] in 2002 to 9100 [2400-19 000] in $2009-\mathrm{a}$ decrease of about $50 \% " 95$ and "[i]n rural Malawi, the provision of antiretroviral therapy has been linked to a 10\% drop in adult mortality between 2004 and 2008. ${ }^{196}$ Another area which should be treated as essential health care is primary health care to pregnant women and their children. There are countries in the region that render such a service for free. For example, South Africa provides free primary health care to children under six and to pregnant women. Fees are also waived at public

\footnotetext{
91 Gerber 2010 www.frost.com. Also see AVERT [date unknown]a www.avert.org; AVERT [date unknown]b www.avert.org; AVERT [date unknown]c www.avert.org.

ILO Zambia 9.

UNAIDS 2010 www.unaids.org.

UNAIDS 2010 www.unaids.org.

UNAIDS 2010 www.unaids.org.

UNAIDS 2010 www.unaids.org.
} 
hospitals for services rendered to indigent persons. In Tanzania (on the Mainland), user fees are not levied for the treatment of children below the age of five and diseases such as tuberculosis and AIDS. ${ }^{97}$

The issue of access to essential health care is, apart from the aforementioned challenges, compounded by the lack of National Health Insurance systems in a majority of SADC countries. The absence of a National Health Insurance system is problematic because: "The public sector is facing a worsening burden of disease as a result of HIV/Aids as well as increasing levels of diseases of poverty. The private sector is attempting to shift HIV/Aids patients and chronic patients onto the state system, as part of the risk selection process. ${ }^{\prime 98}$ It should be noted that there is a proposal in South Africa in favour of a national health insurance scheme.

\subsubsection{Income security: children}

In many SADC countries, there are social protection programmes targeted at orphans and vulnerable children (OVCs). As shown in the table below, these include social assistance benefits and other social services:

SOCIAL PROTECTION PROGRAMMES TARGETING CHILDREN IN SELECTED SADC COUNTRIES

\begin{tabular}{|c|c|}
\hline COUNTRY & SOCIAL SECURITY BENEFITS/SOCIAL SERVICES \\
\hline Botswana & $\begin{array}{l}\text { Orphan Care Benefit: Provided to orphaned Batswana } \\
\text { children below the age of } 18 \text { years. It consists of a } \\
\text { monthly food basket, clothing (including a school } \\
\text { uniform), shelter etc, and is payable to the orphan's } \\
\text { caregiver. }\end{array}$ \\
\hline Mozambique & $\begin{array}{l}\text { Minimum Income for School Attendance: Pilot cash } \\
\text { transfer programme. It is aimed at rural poor } \\
\text { households with children (especially girls) of a school- } \\
\text { going age. This programme provides a minimum }\end{array}$ \\
\hline
\end{tabular}

$97 \quad$ ILO Tanzania Mainland 12.

98 Committee of Inquiry Transforming the Present 86. 


\begin{tabular}{|c|c|}
\hline & income ( $\$ 2$ per month per child) for school attendance. \\
\hline South Africa & $\begin{array}{l}\text { - Child Support Grant: Means tested. A monthly grant } \\
\text { paid to primary caregivers in need, who care for } \\
\text { children who are under the age of } 17 \text {. (The grant has } \\
\text { been extended to children up to their } 18^{\text {th }} \text { birthday from } \\
1^{\text {st }} \text { April 2012). } \\
\text { - Care Dependency Grant: Means tested. A monthly } \\
\text { grant paid to a person appointed by a Court as a } \\
\text { caregiver of a child with severe disabilities and in need } \\
\text { of full-time and special care. } \\
\text { Foster Care Grant: No means test. A grant given to a } \\
\text { person who cares for a child who is not her/his own by } \\
\text { birth when the child is placed in the person's custody } \\
\text { by a Court. } \\
\text { - Social Relief of Distress: This is a temporary provision } \\
\text { of assistance intended for persons in such dire material } \\
\text { need that they are unable to meet their or their families' } \\
\text { most basic needs. Social Relief of Distress is issued } \\
\text { monthly or for any other period for a maximum period } \\
\text { of } 3 \text { months. Extension of the period by a further } 3 \\
\text { months may be granted in exceptional cases. }\end{array}$ \\
\hline Zambia & $\begin{array}{l}\text { - Child Protection Programme: Aimed at reducing the } \\
\text { vulnerability of children and youths from abuse and } \\
\text { neglect. }\end{array}$ \\
\hline
\end{tabular}

The value of the social security benefits aimed at children is generally low in the region. However, a general trend has emerged in the last few years whereby some SADC countries have progressively increased the monetary value of the benefits. For example, Namibia increased its orphans and vulnerable children's benefit by $\mathrm{N} \$ 30$ during the 2010/2011 fiscal year. South Africa has increased the Rand value of the children's grants as follows: 
CHILDREN'S SOCIAL GRANTS VALUE, 2009/2010 2010/2011 AND 2011/2012

\begin{tabular}{|l|l|l|l|l|}
\hline Social grant & $\mathbf{2 0 0 9 / 2 0 1 0}$ & $\mathbf{2 0 1 0 / 2 0 1 1}$ & $\mathbf{2 0 1 1 / 2 0 1 2}$ & Increase \\
\hline Child support* & R240 & R250 & R270 & R20 \\
\hline Foster care & R680 & R710 & R740 & R30 \\
\hline Care dependency & R1 010 & R1 080 & R1 140 & R60 \\
\hline * Increase of R10 in April and R10 in October 2011. \\
\hline
\end{tabular}

Source: National Treasury 2011 www.treasury.gov.za 101.

Furthermore, countries such as South Africa are progressively extending the age of eligibility for some of their children's grants. The child support grant in that country will be gradually extended to children up to their $18^{\text {th }}$ birthday with effect from 1 January $2010 .^{99}$ It is anticipated that an additional 2 million children from indigent families and households will benefit from the child support grant in the next three years. ${ }^{100}$ The total number of children benefiting from the child support grant is expected to escalate from 9.1 million in December 2009 to 11.5 million in March 2013. The phased extension of the child support grant is predicted to require additional budgetary allocations in the next three years as follows: R1.2 billion in 2010/2011, R3.1 billion in 2011/2012, and R5 billion in 2012/2013. ${ }^{101}$

\subsubsection{Assistance: unemployed and poor}

Social assistance rendered to the unemployed and the poor is limited in SADC countries. With the exception of Mauritius, which operates a non-contributory benefit programme aimed at unemployment called Unemployment Hardship Relief, ${ }^{102}$ none of the other SADC countries has an unemployment assistance programme. It should be noted that the labour laws of the majority of SADC countries make provision for

99 Gordhan 2010 www.info.gov.za/

100 National Treasury 2010 www.treasury.gov.za 104.

101 National Treasury 2010 www.treasury.gov.za 104.

102 Unemployment Hardship Relief is - according to the Ministry of Social Security [date unknown] www.gov.mu: "payable to an unemployed person with family responsibility where the income of the household is not sufficient to meet the needs of the members of the household (UHR). The person concerned should be registered as unemployed at the Employment Exchange, is willing and able to take up employment and is actively looking for work." 
severance pay in the event that an employee is dismissed due to the operational requirements of the employer. ${ }^{103}$ Nevertheless, severance pay is not and should not be viewed as a substitute for proper unemployment benefits. The point is that in accordance with international standards "unemployment benefits should be periodical payments, not a one-off payment, on the one hand; while on the other, the one-sided situation where the individual employer bears total liability, replacing the element of risk-pooling and solidarity inherent in social security may lead to adverse selections in hiring decisions as well as evasion; both eroding coverage..$^{104}$ In addition, the entitlement to severance pay is limited to formal sector employment. As a result, informal sector workers cannot benefit from severance pay. ${ }^{105}$

Although there is a shortage of unemployment assistance schemes in the SADC region, universal or means-tested non-contributory schemes, where such schemes exist, do play an indirect unemployment assistance role. This view is informed by the fact that persons covered under this scheme are, generally speaking, needy and too young, old or disabled to participate in the labour market. Furthermore, these benefits are in some countries reported to have the propensity to percolate through (by mean of informal transfers) to other needy individuals living with the beneficiaries. ${ }^{106}$ However, this has the effect of diluting the poverty alleviation impact of the benefits to the intended beneficiaries. The categorical nature of the noncontributory schemes in the regions has led to a situation in which not all poor persons are covered by the schemes. This, it seems, follows from an assumption that able-bodied persons who are sufficiently old or young will earn a living from participating in the labour market. On the contrary, the shortage of job opportunities leaves many such persons destitute. It is therefore important that the scope of coverage of the non-contributory schemes be progressively widened to cover more needy members of the society.

Mpedi 2008 ZIAS 271.

ILO World Social Security Report 59.

Mpedi 2008 ZIAS 271.

Mpedi 2008 ZIAS fn 48. 


\subsubsection{Income security: the elderly and persons with disabilities}

As remarked earlier, two kinds of non-contributory schemes are identifiable in the SADC region, i.e.: universal and means-tested programmes. Botswana, Mauritius and Namibia operate universal schemes. South Africa, on the other hand, has a means-tested social assistance programme offering social grants among others to the indigent elderly members of the population ${ }^{107}$ and persons with disabilities. ${ }^{108}$ Botswana has a universal old-age pension programme. This programme covers all citizens of Botswana who are 65 years of age or older. ${ }^{109}$ Disability benefits are provided in that country under the destitute programme. ${ }^{110}$ The Mauritius universal programme, unlike that of Botswana, makes provision for an old-age pension, a disability pension and a survivor pension. The Namibian scheme, on the other hand, provides cash benefits for old age, disability, child support and foster-parent care. ${ }^{111}$

Several points of criticism can be levelled against the non-contributory schemes found in the region. Firstly, their scope of coverage is limited. This is largely due to the fact that such schemes are largely territorial and nationality-based. In addition, they are generally based in urban areas - much to the neglect of the rural poor. The situation is made worse by the ignorance and high illiteracy rates commonly found in rural areas. ${ }^{112}$ Secondly, the monetary value of the benefits is generally low. This means that the benefits fail to adequately meet the needs of the beneficiaries. Thirdly, some of these schemes are faced with administrative and institutional challenges such as poor levels of service, corruption and fraud. As regards the means-tested benefits, it is true that means testing fulfils a legitimate role, i.e. ensuring that only the poor benefits. Nonetheless, it must to be said that they also have their disadvantages. As pointed out in the South African 2011 Budget Review: "They are complicated. They prevent poor households whose income is marginally above the threshold from receiving support. They increase administrative costs. They can have adverse consequences on people's behaviour - for example, by

Section 9 Social Assistance Act 13 of 2004.

Section 10 Social Assistance Act 13 of 2004.

Ntseane and Solo "Social Protection in SADC" 73.

See Ntseane and Solo "Social Protection in SADC" 81-83 for further reading on this programme.

See Schleberger Namibia's Universal Pension Scheme.

See, for example, Ntseane and Solo "Social Protection in SADC" 73. 
creating an incentive for older workers to divest their assets and liquidate savings prior to retirement." 113

Notwithstanding the foregoing, it should be pointed out that there are positive developments in some countries of the region, aimed at countering these challenges. South Africa has widened the scope of coverage of its old age grant by equalising the age of eligibility at 60 years between males and females. In addition, Lesotho, Namibia, South Africa and Swaziland have increased the value of (some of) their social assistance benefits aimed at the elderly or persons with disabilities. Lesotho raised the value of the old age pension from M200 -M300 at an additional cost of M95.2 million during the 2009/2010 fiscal year. ${ }^{114}$ Namibia increased its old age grant during the $2009 / 2010$ fiscal year by $21.6 \%$ to $N \$ 450$ per month. ${ }^{115}$ A further increase to the old age grant of $\mathrm{N} \$ 50$ was implemented for the 2010/2011 financial year. ${ }^{116}$ Apart from the old age grant, ${ }^{117}$ Swaziland increased its old age grant in 2009 from E500 to E600 per quarter. ${ }^{118}$ South Africa, on the other hand, increased the value of its old age grant and disability benefit as follows:

VALUE OF OLD AGE AND DISABILITY GRANTS 2009/2010 2010/2011 AND $2011 / 2012$

\begin{tabular}{|l|l|l|l|l|}
\hline Social grant & $\mathbf{2 0 0 9 / 2 0 1 0}$ & $\mathbf{2 0 1 0 / 2 0 1 1}$ & $\mathbf{2 0 1 1 / 2 0 1 2}$ & Increase \\
\hline Old age & $\mathrm{R} 1010$ & $\mathrm{R} 1080$ & $\mathrm{R} 1140$ & $\mathrm{R} 60$ \\
\hline Old age, over 75s & $\mathrm{R} 1010$ & $\mathrm{R} 1080$ & $\mathrm{R} 1160$ & $\mathrm{R} 80$ \\
\hline Disability & $\mathrm{R} 1010$ & $\mathrm{R} 1080$ & $\mathrm{R} 1140$ & $\mathrm{R} 60$ \\
\hline
\end{tabular}

Source: National Treasury 2011 www.treasury.gov.za 101.

Furthermore, to counter the problems associated with the inaccessibility of the socalled deep-rural areas, South Africa implemented a programme called the Integrated Registrations Community Outreach Programme (ICROP). This

113 National Treasury 2011 www.treasury.gov.za 101.

114 Thahane 2009 www.gov.ls 21.

115 Kuugongelwa-Amadhila 2010 www.mof.gov.na 11.

116 Kuugongelwa-Amadhila 2010 www.mof.gov.na 18.

117 Kuugongelwa-Amadhila 2010 www.mof.gov.na 18.

118 Swaziland Ministry of Finance 2009 www.gov.sz. 
programme involves the deployment of 40 mobile offices in deep rural areas to serve the communities that would otherwise have been inaccessible and therefore unable to apply for social grants. ${ }^{119}$ The programme has been criticised on the basis that this is a temporary solution and leads to "the depletion of human resource capacity at local offices, as some of the existing staff members [are] deployed to mobile offices." $^{120}$ The ICROP is to therefore to be seen as an interim solution. A more permanent solution has to be found. This could involve the establishment of permanent offices and the employment of additional personnel.

\subsection{Mandatory social insurance}

Mandatory insurance schemes are limited in the SADC. The most notable are the unemployment insurance scheme and worker compensation schemes. South Africa has a compulsory unemployment insurance scheme ${ }^{121}$ which provides short-term benefits such as unemployment benefits, illness benefits, maternity benefits, adoption benefits and dependants' benefits. ${ }^{122}$ These benefits are financed through employer and employee contributions. ${ }^{123}$ The State normally finances any deficits that may accrue. Apart from South Africa, there are countries which operate insurance-based schemes which provide short-term unemployment protectionrelated benefits such as maternity and sickness benefits. The Namibian Maternity, Sickness, and Death (MSD) Fund, for example, makes provision inter alia for maternity benefits and sickness benefits. ${ }^{124}$ The contribution rate towards the MSD Fund is set at $1.8 \%$ of the employee's basic salary, shared equally by the employer $(0.9 \%)$ and the employee $(0.9 \%) .{ }^{125}$ Several points of criticism may be levelled against contributory schemes in the region. Firstly, the scope of coverage is often limited to the formal sector. Consequently, they tend to exclude informal sector workers, part-time workers, casual and temporary workers. Secondly, they pay more attention to the compensation of victims of social risks and neglect than other

\footnotetext{
119 SASSA Annual Report 2007/2008 8.

120 SASSA Annual Report 2007/2008 17

121 See the Unemployment Insurance Act 63 of 2001 and the Unemployment Insurance Contributions Act 4 of 2002.

122 Parts B-F Unemployment Insurance Act 63 of 2001.

123 Section 5(1) Unemployment Insurance Contributions Act 4 of 2002.

124 Social Security Commission [date unknown] www.ssc.org.na.

125 Tweya "Extending Social Security Coverage".
} 
pertinent aspects such as the prevention of social risks and the (re)integration of affected persons into the labour market.

Workers' compensation schemes, unlike unemployment insurance schemes, can be found throughout the SADC region. ${ }^{126}$ These schemes make provision for the compensation of the victims of occupational injuries and diseases. They also make provision for the payment of survivors' benefits, which are paid out when, for instance, a breadwinner loses his/her life during the course of employment. Workers' compensation schemes in the region are largely no-fault based. Employees are entitled to compensation regardless of whether or not their injury or illness is caused by the fault of their employer or any other person. Employers carry the responsibility for contributing towards the workers' compensation schemes.

Apart from the foregoing, the general tendency apparent in the SADC region is that, with the exception of the unemployment insurance scheme in South Africa and the workers' compensations schemes, there is a widespread lack of a statutory duty on the part of individuals to contribute to or belong to a variety of social insurance schemes. It should be admitted that the contract of employment and collective agreements do, in some instances, make participation in employment-based retirement and medical schemes mandatory for employees. Despite that, the lack of statutory compulsion on individuals to participate in retirement and medical aid schemes means that myopic employees and, in some instances, their families will eventually rely on tax-financed social security interventions providing old age benefits and medical care. Consequently, they will impose an unnecessary burden on limited state resources. This is contrary to the hypothesis that individuals who can afford to secure themselves (and their families) should (be compelled to) do so and only those that cannot afford to do so may be looked after by the state.

\subsection{Voluntary schemes}

Voluntary social insurance is, unlike private insurance, not widespread in SADC countries. In Seychelles an insured person may pay additional voluntary

126 Fultz and Pieris " 1999 International Labour Review 171. 
contributions to the Seychelles pension fund. Notwithstanding the dearth of voluntary insurance schemes, it must be noted that there is a variety of commercial insurance products on the market in the region. These products cater for social risks ranging from invalidity to old age and are available (usually) on a voluntary basis to all who can afford the monthly premiums. Nevertheless, private insurance is a luxury that not all persons can afford. Firstly, some self-employed persons have unreliable and at times irregular incomes. To this end, the probability of private insurance policy lapses is high among the poor and all of those involved in precarious forms of employment - particularly those who eke out a living in the informal sector. Apart from the aforementioned commercial insurance products, there are employer-based private insurance schemes (e.g. medical aid schemes and retirement funds). Participation in these schemes is as a rule restricted to the employees of a particular employer. In addition, employees' contributions towards these schemes are largely subsidised by their employers.

\section{Conclusions}

The minimum social protection floor concept is a fairly recent development. However, as shown in this paper, there are regional and national social protection initiatives which, although they preceded the concept, do fall within its scope. The SADC and in member states will need to build on these initiatives to improve social protection in the region and their respective borders. It is of the utmost importance that in improving social protection systems the focus should be not only on compensating persons when social risks occur. Special attention should also be paid to the prevention of social risks and the (re-)integration of affected persons into the labour market and society in general. Furthermore, the minimum social protection floor ideal does not operate in isolation. It is interlinked with mandatory and voluntary insurance schemes. 


\section{Bibliography}

Chitambo "SADC Policy Dimensions"

Chitambo A "SADC Policy Dimensions of Social Protection" (Unpublished paper presented at the SADC Social Security Consultative Workshop Towards the Development of Social Protection in the SADC Region Helderfontein Conference Centre Johannesburg 17-19 October 2001)

Cichon "Expert Panel on Emerging Issues"

Cichon M "Expert Panel on Emerging Issues: Social Protection: The UN CEB Social Protection Floor Initiative" (Unpublished paper delivered at the Commission for Social Development 49th session New York 14 February 2011)

Cichon, Behrendt and Wodsak UN Social Protection Floor Initiative

Cichon M, Behrendt C and Wodsak V The UN Social Protection Floor Initiative: Turning the Tide at the ILO Conference 2011 (Friedrich Ebert Stiftung Berlin 2011)

Committee of Inquiry Social Security

Committee of Inquiry into a Comprehensive System of Social Security for South Africa Social Security within a Regional Context. Committee Report No. 14 (The Committee Pretoria 2002)

Committee of Inquiry Transforming the Present

Committee of Inquiry into a Comprehensive System of Social Security for South Africa Transforming the Present - Protecting the Future: Consolidated Report (The Committee Pretoria 2002)

Fultz and Pieris Social Protection for Migrant Workers

Fultz E and Pieris B The Social Protection for Migrant Workers in South Africa (ILO/SAMAT Harare 1997) 
Fultz and Pieris Social Security Schemes

Fultz E and Pieris B Social Security Schemes in Southern Africa: An Overview and Proposals for Future Development (ILO/SAMAT Geneva 1999)

Fultz and Pieris 1999 International Labour Review

Fultz E and Pieris B "Compensation for employment injuries in Southern Africa: An overview of schemes and proposals for reform" 1999 International Labour Review 171-193

ILO Extending Social Security International Labour Organisation Extending Social Security to All: A Guide through Challenges and Options (ILO Geneva 2010)

ILO Tanzania Mainland

International Labour Organisation Tanzania Mainland: Social Protection Expenditure and Performance Review and Social Budget - Executive Summary (ILO Geneva 2008)

ILO World Social Security Report

International Labour Organisation World Social Security Report 2010/2011: Providing Coverage in Times of Crisis and Beyond (ILO Geneva 2010)

ILO Zambia

International Labour Organisation Zambia: Social Protection Expenditure and Performance Review and Social Budget - Executive Summary (ILO Geneva 2008)

ILO and WHO Social Protection Floor

International Labour Organisation and World Health Organisation The Social Protection Floor (A Joint Crisis Initiative of the UN Chief Executives Board for Co-ordination on the Social Protection Floor) (ILO/WHO Geneva 2009) 
ILO and WHO Social Protection Floor Initiative

International Labour Organisation and World Health Organisation Social Protection Floor Initiative (ILO/WHO Geneva 2010)

International Organisation of Employers Concept of the Social Protection Floor International Organisation of Employers The Concept of the Social Protection Floor: Explanatory Note for Employers (IOE Geneva 2011)

Moyo 2010 ESR Review

Moyo A "The protection and promotion of socio-economic rights in the SADC Region" 2010 11:3 ESR Review 12-15

Mpedi 2008 ZIAS

Mpedi LG "Unemployment Protection in the Southern African Development Community: Trends and Challenges" 2008 ZIAS 271-296

Ntseane and Solo "Social Protection in SADC"

Ntseane D and Solo K "Social Protection in SADC: Developing an Integrated and Inclusive Framework - The Case of Botswana" in Olivier MP and Kalula ER (eds) Social Protection in SADC: Developing an Integrated and Inclusive Framework (CICLASS Johannesburg 2004)

Olivier and Kalula "Regional Social Security"

Olivier MP and Kalula ER "Regional Social Security" in Olivier MP et al (eds) Social Security: A Legal Analysis (LexisNexis Durban 2003)

SASSA Annual Report 2007/2008

South African Social Security Agency Annual Report 2007/2008 (SASSA Pretoria 2008)

Schleberger Namibia's Universal Pension Scheme

Schleberger E Namibia's Universal Pension Scheme: Trends and Challenges (ILO Geneva 2002) 
Taylor 2001 Cooperation South

Taylor V "Social protection challenges in southern Africa" 20012 Cooperation South 49-65

Tweya "Extending Social Security Coverage"

Tweya T "Extending Social Security Coverage: An Overview of Social Security in Namibia" (Unpublished paper presented at the International Social Security Association Meeting of Directors of Social Security Organizations in Englishspeaking Africa Banjul The Gambia 7-9 October 2003)

World Commission on the Social Dimension of Globalization Fair Globalization

World Commission on the Social Dimension of Globalization $A$ Fair Globalization: Creating Opportunities for All (ILO Geneva 2004)

\section{Register of legislation}

Social Assistance Act 13 of 2004

Unemployment Insurance Act 63 of 2001

Unemployment Insurance Contributions Act 4 of 2002

\section{Register of international instruments}

Declaration and Treaty of SADC (1992)

Charter of Fundamental Social Rights in SADC (2003)

International Covenant on Economic, Social and Cultural Rights (1966)

Convention on the Rights of the Child (1989)

Convention on the Elimination of All Forms of Discrimination Against Women (1979)

\section{Register of Internet sources}

Africa Civil Society Platform for Social Protection 2008 www.ipc-undp.org Africa Civil Society Platform for Social Protection 2008 Investing in Social Protection in Africa: Statement to the First African Union Conference for 
Ministers with Responsibility for Social Development http://www.ipcundp.org/doc_africa_brazil/CSO_Statement-AU_Ministerial_Meeting.pdf [date of use 13 March 2012]

AVERT [date unknown]a www.avert.org

AVERT [date unknown] HIV and Aids in Lesotho http://www.avert.org/aidslesotho.htm [date of use 13 March 2012]

AVERT [date unknown]b www.avert.org

AVERT [date unknown] HIV and Aids in Malawi http://www.avert.org/aidsmalawi.htm [date of use 13 March 2012]

AVERT [date unknown]c www.avert.org

AVERT [date unknown] HIV and Aids in Tanzania http://www.avert.org/aidstanzania.htm [date of use 13 March 2012]

Gerber 2010 www.frost.com

Gerber J 2010 Healthcare in SADC: An un-pruned rose bush http://www.frost.com/prod/servlet/market-insight-top.pag?docid=209147778 [date of use 13 March 2012]

Gordhan 2010 www.info.gov.za

Gordhan P 2010 Budget Speech 2010 (South Africa) http://www.info.gov.za/ speeches/2010/10021715051004.htm [date of use 13 March 2012]

ILO [date unknown] www.ilo.org

International Labour Organisation [date unknown] Facts on Social Security in Africa

http://www.ilo.org/public/english/protection/socsec/pol/campagne/files/africafacts heet.pdf [date of use 13 March 2012] 
Kuugongelwa-Amadhila 2010 www.mof.gov.na

Kuugongelwa-Amadhila S 2010 Statement for the 2010/11 Budget (Namibia) http://www.mof.gov.na/Budget\%20Documents/budget\%202010/30\%203\%2010_ -_Budget_Speech_2010_vFINALtuesday.pdf [date of use 13 March 2012]

Ministry of Social Security [date unknown] www.gov.mu

Ministry of Social Security, National Solidarity and Senior Citizens Welfare and Reform Institutions (Mauritius) [date unknown] Services for Social Aid http://www.gov.mu/portal/site/ssnssite/menuitem.99ee6c542c31b80e8f77861084 d521ca/ [date of use 13 March 2012]

National Treasury 2010 www.treasury.gov.za

National Treasury (Republic of South Africa) 20102010 Budget Review http://www.treasury.gov.za/documents/national\%20budget/2010/review/default.a spx [date of use 13 March 2012]

National Treasury 2011 www.treasury.gov.za

National Treasury (Republic of South Africa) 20112011 Budget Review http://www.treasury.gov.za/documents/national\%20budget/2011/review/Budget\% 20Review.pdf [date of use 13 March 2012]

Social Security Commission [date unknown] www.ssc.org.na

Social Security Commission (Namibia) [date unknown] Maternity, Sickness and Death Fund http://www.ssc.org.na/index.php?option=com_content\&view=article \&id=47 [date of use 13 March 2012]

SADC [date unknown] www.sadc.int

Southern African Development Community [date unknown] About SADC http://www.sadc.int/english/about-sadc/ [date of use 27 October 2011] 
SADC 2006 www.ansa-africa.net

South African Development Community 2006 Towards an African regional social policy" Johannesburg Draft SADC Ministerial Meeting Johannesburg (November 2006) http://www.ansa-africa.net/uploads/documents/publications/UN_DESA_ SADC_Johannesburg_Nov2006.pdf [date of use 13 March 2012]

Swaziland Ministry of Finance 2009 www.gov.sz

Swaziland Ministry of Finance 2009 Budget Speech http://www.gov.sz/ index.php?option=com_content\&view=article\&id=702\&ltemid $=574$ [date of use 13 March 2012]

Thahane 2009 www.gov.ls

Thahane TT 2009 Budget Speech to Parliament for the 2009/2010 Fiscal Year (Lesotho) http://www.gov.Is/articles/2009/Budget_Speech_2009-10.pdf [date of use 13 March 2012]

UNAIDS 2010 www.unaids.org

UNAIDS 2010 Global Report - Fact Sheet: Sub-Saharan Africa http://www. unaids.org/documents/20101123_FS_SSA_em_en.pdf [date of use 13 March 2012]

Von Benda-Beckmann and Kirsch [date unknown] www.gtz.de

Von Benda-Beckmann F and Kirsch R [date unknown] Informal security systems in Southern Africa and approaches to strengthen them through public policy measures http://www.gtz.de [date of use 1 November 2011] 


\section{List of abbreviations}

$\begin{array}{ll}\text { AU } & \text { African Union } \\ \text { ILO } & \text { International Labour Organisation } \\ \text { SADC } & \text { Southern African Development Community } \\ \text { UN } & \text { United Nations } \\ \text { WHO } & \text { World Health Organisation } \\ \text { ZIAS } & \text { Zeitschrift für ausländisches und internationals Arbeits- und Sozialrecht }\end{array}$ 